\title{
IMPLEMENTASI ALGORITMA $A N T$ COLONY OPTIMIZATION PADA APLIKASI PENCARIAN LOKASI TEMPAT IBADAH TERDEKAT DI KOTA BANDUNG
}

\author{
Andri Zarman ${ }^{1}$,Mohamad Irfan ${ }^{2}$, Wisnu Uriawan ${ }^{3}$ \\ 1,2,3 Jurusan Teknik Informatika, Fakultas Sains dan Teknologi \\ Universitas Islam Negeri Sunan Gunung Djati Bandung \\ Jl. A.H. Nasution 105, Bandung 40614 Indonesia \\ ${ }^{1}$ andri.informatika@gmail.com, ${ }^{2}$ irfan.bahaf@uinsgd.ac.id, ${ }^{3}$ wisnu_u@uinsgd.ac.id
}

\begin{abstract}
Abstrak-Indonesia merupakan negara yang penduduknya memeluk berbagai agama, yaitu di antaranya agama: Islam, Kriten, Budha, Hindu. Bandung merupakan kota yang banyak wisatawannya, baik wisatawan lokal maupun mancanegara, fasilitas umum yang ada di Kota Bandung dibutuhkan, salah satunya tempat ibadah. Informasi tentang tempat ibadah cukup diperlukan oleh para wisatawan, karena cukup sulit mendapatkan informasi tempat ibadah di Kota Bandung, khususnya sulit dalam mendapatkan rute terdekat (shourtest paht) menuju tempat ibadah tersebut. Penelitian ini dibuat untuk merancang sebuah aplikasi yang memberikan informasi serta petunjuk arah tempat ibadah di Kota Bandung, dengan menerapkan Algoritma Ant Colony Optimization. Aplikasi ini digunakan pada perangkat Smatrphone/Android, oleh karena itu, aplikasi ini cukup flexibel untuk digunakan. Aplikasi ini menggunakan dukungan web service, sehingga data mudah di inputkan oleh admin.
\end{abstract}

Kata kunci: Algoritma Ant Colony Optimization, Tempat Ibadah, Rute Terdekat.

\section{I.PENDAHULUAN}

Sistem informasi geografis merupakan media informasi yang sangat dibutuhkan dalam kebutuhan ber-transportasi. Menurut Menurut Linden (1987), Melalui Sistem Informasi Geografis manusia bisa mendapatkan informasi berupa peta secara spasial terkait dengan muka bumi [1], misalnya manusia kesulitan mencari suatu tempat/lokasi dalam perjalan, maka sistem informasi geografis ini dimanfaatkan untuk mencari lokasi yang dibutuhkan dan menampilkan peta yang berisikan lokasi yang dibutuhkan tersebut.

Salah satu teknologi sistem informasi goegrafis yang sedang berkembang saat ini ialah pencarian rute terdekat (shoutest path). Rute terdekat menjadi pilihan bagi setiap orang karena dapat menghemat banyak waktu bagi mereka untuk sampai di tempat tujuan. Umumnya dari mereka yang memilih adalah wisatawan lokal maupun mancanegara yang sedang mencari tempat wisata atau sekedar singgah dan mencari tempat untuk beristirahat bahkan mereka yang ingin mencari tempat ibadah untuk bersembahyang.Kota besar seperti Bandung memiliki banyak lokasi penting yang dapat dikunjungi wisatawan. Badan Pusat Statistik (BPS) mencatat kunjungan wisatawan pada Oktober 2015 menembus 10.722 orang, ini mengindikasikan bahwa banyaknya wisatawan yang datang ke kota Bandung dengan berbagai kepentingan dan tidak sedikit dari mereka datang mencari tempat ibadah disela-sela kepentingannya. Tempat ibadah yang terdapat di kota Bandung seperti mesjid untuk umat yang beragama islam, gereja untuk umat kristiani, wihara intuk umat budha, pura untuk umat hindu tersebar hingga ke pelosok daerah tepi kota Bandung.

Pencarian rute terdekat lokasi tempat ibadah merupakan salah satu pencarian yang diperlukan oleh para wisatawan yang datang ke Kota Bandung, dengan adanya aplikasi pencarian rute terdekat ini, maka akan memudahkan para wisatawan untuk mendapatkan rute perjalan menuju lokasi tersebut, dengan menampilkan peta yang dilengkapi rute menuju lokasi tersebut.

Memaknai pentingnya pencarian rute terdekat terhadap para wisatawan, banyak Algoritma pencarian rute terdekat yang dikembangkan hingga saat ini. Menurut (Dorigo, 1996) Koloni semut merupakan algoritma yang bersifat heuristik untuk menyelesaikan masalah optimasi [2]. Algoritma Ant Colony Optimization. Algoritma (ACO) ini merupakan algoritma yang sangat unik dibandingkan dengan Algoritma Pencarian rute terdekat lainnya, dikarenakan Algoritma ini diadopsi dari Koloni Semut yang sedang mencari makanan dari sarang menuju sumber makanan, dengan meninggalkan suatu jejak kaki yang disebut Pheromon. 


\section{II.TINJAUAN PUSTAKA}

\section{A. Tempat Ibadah}

\section{Masjid}

Menurut (Mohammad E. Ayub. Manajemen Masjid, Jakarta: Gema Insani Press. 1996) Masjid berasal dari bahasa arab sajada yang berarti tempat bersujud atau tempat menyembah Allah SWT. Selain itu, masjid juga merupakan tempat orang berkumpul dan melaksanakan shalat secara berjama'ah dengan tujuan meningkatkan solidaritas dan silaturrahmi dikalangan kaum muslimin, dan di masjid pulalah tempat terbaik untuk melangsungkan shalat jum'at.[3] Sebagai firman Allah dalam surat Al-Jin ayat: 18

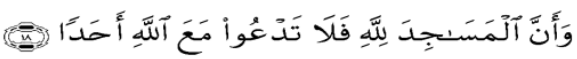

Artinya: "Dan sesungguhnya masjid-masjid itu adalah kepunyaan Allah. Maka janganlah kamu menyembah seseorangpun di dalamnya di samping (menyembah) Allah." (Qs. AlJin: 18) ${ }^{2}$. (Depag RI, 1996: 457)

2. Gereja

Kata Gereja berasal dari kata dalam bahasa Yunani "Ekklesia" yang didefinisikan sebagai "perkumpulan" atau "orang-orang yang dipanggil keluar." Akar kata "Gereja" tidak berhubungan dengan gedung, tetapi dengan orang. Menjadi ironis bahwa saat Saudara bertanya kepada orang mereka pergi ke gereja mana, biasanya mereka akan mengatakan Baptis, Metodis, atau denominasi lainnya. Seringkali mereka merujuk pada denominasi atau pada suatu bangunan.

Roma 16:5 berkata, "Salam juga kepada jemaat di rumah mereka..." Paulus merujuk pada Gereja di rumah mereka, bukan pada gedung gereja, namun kumpulan orang-orang percaya.

Gereja itu tubuh Kristus. Efesus 1:22-23 mengatakan, "Dan segala sesuatu telah diletakkan-Nya di bawah kaki Kristus dan Dia telah diberikan-Nya kepada jemaat sebagai Kepala dari segala yang ada. Jemaat yang adalah tubuh-Nya, yaitu kepenuhan Dia, yang memenuhi semua dan segala sesuatu." Tubuh Kristus terdiri dari semua orang percaya, mulai dari Pentakosta sampai Pengangkatan.

3. Wihara

Wihara adalah rumah ibadah agama Buddha, bisa juga dinamakan kuil. Klenteng adalah rumah ibadah penganut taoisme, maupun konfuciusisme. Tetapi di Indonesia, karena orang yang ke wihara/kuil/klenteng umumnya adalah etnis Tionghoa, maka menjadi agak sulit untuk dibedakan, karena umumnya sudah terjadi sinkritisme antara Buddhisme, Taoisme, dan Konfuciusisme. Salah satu contohnya adalah Vihara Kalyana Mitta yang terletak di daerah Pekojan, Jakarta Barat.

Banyak umat awam yang tidak mengerti perbedaan antara klenteng dan wihara. Klenteng dan wihara pada dasarnya berbeda dalam arsitektur, umat dan fungsi. Klenteng pada dasarnya berarsitektur tradisional Tionghoa dan berfungsi sebagai tempat aktivitas sosial masyarakat selain fungsi spiritual. Wihara berarsitektur lokal dan biasanya mempunyai fungsi spiritual saja. Namun, wihara juga ada yang berarsitektur tradisional Tionghoa seperti pada wihara Buddhis aliran Mahayana yang memang berasal dari Tiongkok.

Perbedaan antara klenteng dan wihara kemudian menjadi rancu karena peristiwa G30S pada tahun 1965. Imbas peristiwa ini adalah pelarangan kebudayaan Tionghoa, termasuk kepercayaan tradisional Tionghoa, oleh pemerintah Orde Baru. Klenteng yang ada pada masa itu terancam ditutup secara paksa. Banyak klenteng yang kemudian mengadopsi istilah dari bahasa Sanskerta ataupun bahasa Pali, mengubah nama sebagai wihara dan mencatatkan surat izin dalam naungan agama Buddha demi kelangsungan peribadatan. Dari sinilah kemudian umat awam sulit membedakan klenteng dengan wihara.

Setelah Orde Baru digantikan oleh Orde Reformasi, banyak wihara yang kemudian mengganti nama kembali ke nama semula yang berbau Tionghoa dan lebih berani menyatakan diri sebagai klenteng daripada wihara.

\section{Pura}

Menurut Sudharta, Tjok. Rai (2006) Pura adalah istilah untuk tempat ibadah agama Hindu di Indonesia. Pura di Indonesia terutama terkonsentrasi di Bali sebagai pulau yang mempunyai mayoritas penduduk penganut agama Hindu.[4]

Kata "Pura" sesungguhnya berasal dari akhiran bahasa Sanskerta (-pur, -puri, -pura, -puram, -pore), yang artinya adalah kota, kota berbenteng, atau kota dengan menara atau istana. Dalam perkembangan pemakaiannya di Pulau Bali, istilah "Pura" menjadi khusus untuk tempat ibadah; sedangkan istilah "Puri" menjadi khusus untuk tempat tinggal para raja dan bangsawan.

Tidak seperti candi atau kuil Hindu di India yang berupa bangunan tertutup, pura dirancang sebagai tempat ibadah di udara terbuka yang terdiri dari beberapa lingkungan yang dikelilingi tembok. Masingmasing lingkungan ini dihubungkan dengan gerbang atau gapura yang penuh berukiran indah. Lingkungan yang dikelilingi tembok ini memuat beberapa bangunan seperti pelinggih yaitu tempat suci bersemayam hyang, meru yaitu menara dengan atap bersusun, serta bale (pendopo atau paviliun). Struktur tempat suci pura mengikuti konsep Trimandala, yang memiliki tingkatan pada derajat kesuciannya, yakni:

- $\quad$ Nista mandala (Jaba pisan): zona terluar yang merupakan pintu masuk pura dari lingkungan luar. Pada zona ini biasanya berupa lapangan atau taman yang dapat digunakan untuk kegiatan pementasan tari atau tempat persiapan dalam melakukan berbagai upacara keagamaan.

- $\quad$ Madya mandala (Jaba tengah): zona tengah tempat aktivitas umat dan fasilitas pendukung. Pada 
zona ini biasanya terdapat Bale Kulkul, Bale Gong (Bale gamelan), Wantilan (Bale pertemuan), Bale Pesandekan, dan Perantenan.

- Utama mandala (Jero): yang merupakan zona paling suci di dalam pura. Di dalam zona tersuci ini terdapat Padmasana, Pelinggih Meru, Bale Piyasan, Bale Pepelik, Bale Panggungan, Bale Pawedan, Bale Murda, dan Gedong Penyimpenan.

Meskipun demikian tata letak untuk zona Nista mandala dan Madya mandala kadang tidak mutlak seperti demikian, karena beberapa bangunan seperti Bale Kulkul, atau Perantenan atau dapur pura dapat pula terletak di Nista mandala.

\section{B. Ant Colony Optimization}

Algoritma Semut diadopsi dari perilaku koloni semut yang dikenal sebagai sistem semut (Dorigo, 1996) [5]. Secara alamiah koloni semut mampu menemukan rute terpendek dalam perjalanan dari sarang ke tempat-tempat sumber makanan.
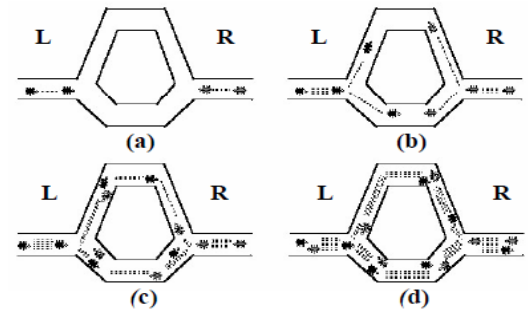

Gambar 1. Perjalanan semut menemukan sumbermakanan.

Koloni semut dapat menemukan jalur terpendek antara sarang dan sumber makanan berdasarkan jejak kaki pada lintasan yang telah dilewati. Semakin banyak semut yang melewati suatu lintasan maka semakin jelas bekas jejak kakinya. Hal ini menyebabkan lintasan yang dilalui semut dalam jumlah sedikit semakin lama semakin berkurang kepadatan semut yang melewatinya, atau bahkan akan tidak dilewati sama sekali. Sebaliknya lintasan yang dilalui semut dalam jumlah banyak semakin lama akan semakin bertambah kepadatan semut yang melewatinya atau bahkan semua semut melewati lintasan tersebut.

Gambar 1.a menujukkan perjalanan semut dalam menemukan jalur terpendek dari sarang ke sumber makanan, terdapat dua kelompok semut yang melakukan perjalanan. Kelompok semut L berangkat dari arah kiri ke kanan dan kelompok semut $\mathrm{R}$ berangkat dari kanan ke kiri. Kedua kelompok berangkat dari titik yang sama dan dalam posisi pengambilan keputusan jalan sebelah mana yang akan diambil. Kelompok L membagi dua kelompok lagi. Sebagian melewati jalan atas dan sebagian melewati jalan bawah. Hal ini juga berlaku pada kelompok R. Gambar 1.b dan Gambar 1.c menunjukkan bahwa kelompok semut berjalan pada kecepatan yang sama dengan meninggalkan feromonatau jejak kaki di jalan yang telah dilalui. Feromon yang ditinggalkan oleh kumpulan semut yang melewati jalan atas telah mengalami banyak penguapan karena semut yang melewati jalan atas berjumlah lebih sedikit dibandingkan jalan yang di bawah. Hal ini disebabkan jarak yang ditempuh lebih panjang dibandingkan jalan bawah. Sedangkan feromon yang berada pada bagian bawah penguapannya cenderung lebih lama. Karena semut yang melewati jalan bawah lebih banyak daripada semut yang melewati jalan atas. Gambar 1.d menunjukkan bahwa semut-semut yang lain pada akhirnya memutuskan untuk melewati jalan bawah karena feromon yang ditinggalkan masih banyak, sedangkan feromon pada jalan atas sudah banyak menguap sehingga semut-semut tidak memilih jalan atas. Semakin banyak semut yang melewati jalan maka semakin banyak semut yang mengikutinya, semakin sedikit semut yang melewati jalan, maka feromon yang ditinggalkan semakin berkurang bahkan hilang. Dari sinilah kemudian terpilihlah jalur terpendek antara sarang dan sumber makanan.

\section{III.METODE PENELITIAN}

Menurut Dorigo, (1996) Koloni semut merupakan algoritma yang bersifat heuristik untuk menyelesaikan masalah optimasi. Algoritma ini diinspirasikan oleh lingkungan koloni semut pada saat mencari makanan. Semut dapat mencari lintasan terpendek dari suatu sumber makanan menuju sarangnya tanpa harus melihatnya secara langsung. Semut-semut mempunyai penyelesaian yang sangat unik dan sangat maju, yaitu dengan menggunakan jejak pheromon pada suatu jalur untuk berkomunikasi dan membangun solusi, semakin banyak jejak pheromon ditinggalkan maka jalur tersebut akan diikuti oleh semut lain. [5]
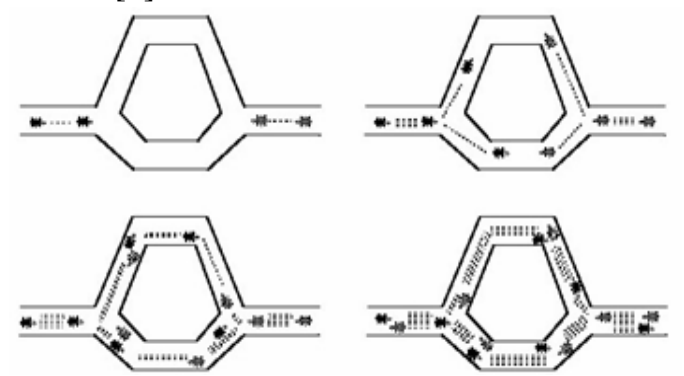

Gambar 2. Semut Dalam Proses Menemukan Sumber Makanan

Dalam algoritma semut, diperlukan beberapa variabel dan langkah-langkah untuk menentukan jarak terpendek.

Langkah 1:

a. Parameter-parameter yang diperlukan pada algoritma semut adalah sebagai berikut:

1. Intensitas jejak semut antar tempat ( $\tau \mathrm{ij})$ dan perubahannya

$\tau \mathrm{ij}$ harus diinisialisasikan sebelum memulai siklus. $\tau \mathrm{ij}$ digunakan dalam persamaan probabilitas tempat yang akan dikunjungi. $\Delta \tau \mathrm{ij}$ diinisialisasikan setelah selesai satu siklus. $\Delta \tau \mathrm{ij}$ digunakan untuk menentukan $\tau \mathrm{ij}$ untuk siklus selanjutnya. 
2. Tetapan siklus semut (Q)

Q merupakan konstanta yang digunakan dalam persamaan untuk menentukan $\Delta \tau \mathrm{ij}$. Nilai $\mathrm{Q}$ ditentukan oleh pengguna.

3. Tetapan pengendali intensitas jejak semut $(\alpha)$ $\alpha$ digunakan dalam persamaan probabilitas tempat yang akan dikunjungi dan berfungsi sebagai pengendali intensitas jejak semut. Nilai $\alpha$ ditentukan oleh pengguna.

4. Tetapan pengendali visibilitas $(\beta)$

$\beta$ digunakan dalam persamaan probabilitas kota yang akan dikunjungi dan berfungsi sebagai pengendali visibilitas. Nilai $\beta$ ditentukan oleh pengguna.

5. Visibilitas antar tempat (

ๆij digunakan dalam persamaan probabilitas tempat yang akan dikunjungi. Nilai ๆij merupakan hasil dari $1 / \eta \mathrm{ij}$ (jarak tempat).

6. Banyak semut (m).

m merupakan banyak semut yang akan melakukan siklus dalam algoritma semut. Nilai m ditentukan oleh pengguna.

7. Tetapan penguapan jejak semut $(\rho)$

$\rho$ digunakan untuk menentukan $\tau$ ij untuk siklus selanjutnya. Nilai $\rho$ ditentukan oleh pengguna.

8. Jumlah siklus maksimum (NCmax)

NCmax adalah jumlah maksimum siklus yang akan berlangsung. Siklus akan berhenti sesuai dengan NCmax yang telah ditentukan atau telah konvergen. Nilai NCmax ditentukan oleh pengguna.

9. Pengisian koordinat tempat

Pada pengisian koordinat tempat dapat diinputkan sesuai dengan yang kita inginkan. Dengan bertambahnya koordinat maka jalur yang ditempuh akan lebih panjang.

b. Inisialisasi tempat pertama setiap semut Setelah inisialisasi $\tau$ ij dilakukan, kemudian $\mathrm{m}$ semut ditempatkan pada tempat pertama tertentu secara acak. Untuk nilai parameter $\alpha$ sebaiknya diberi nilai $0 \leq \alpha \leq$ 1 , hal ini dimaksudkan untuk menghindari akumulasi pheromone yang tidak terbatas pada sisi tersebut. Karena jumlah pheromone yang ditinggalkan tidak mungkin bertambah kuat tetapi akan bertambah kurang. Untuk nilai parameter $\beta$ sebaiknya tidak diberi nilai 0 karena jika diberi nilai 0 maka hasil yang dicapai tidak maksimum. Tidak optimum disini berarti suatu kondisi dimana panjang perjalanan yang dicapai tidak minimum.

Langkah 2:

Pengisian tempat pertama ke dalam tabu list. Hasil inisialisasi tempat pertama setiap semut dalam langkah 1 harus diisikan sebagai elemen pertama tabu list. Hasil dari langkah ini adalah terisinya tabu list setiap semut dengan indeks tempat tertentu, yang berarti bahwa setiap tabuk(1) bisa berisi indeks tempat antara 1 sampai n sebagaimana hasil inisialisasi pada langkah 1 . Langkah 3:
Penyusunan rute kunjungan setiap semut ke setiap tempat. Koloni semut yang sudah terdistribusi ke sejumlah atau setiap tempat, akan mulai melakukan perjalanan dari tempat pertama masing-masing sebagai tempat asal dan salah satu tempat-tempat lainnya sebagai tempat tujuan. Kemudian dari tempat kedua masing-masing, koloni semut akan melanjutkan perjalanan dengan memilih salah satu dari tempattempat yang tidak terdapat pada tabuk sebagai tempat tujuan selanjutnya. Perjalanan koloni semut berlangsung terus menerus sampai semua tempat satu persatu dikunjungi atau telah menempati tabuk. Jika s menyatakan indeks urutan kunjungan, tempat asal dinyatakan sebagai tabuk(s) dan tempat-tempat lainnya dinyatakan sebagai $\{\mathrm{N}$-tabuk\}, maka untuk menentukan tempat tujuan digunakan persamaan probabilitas tempat untuk dikunjungi sebagai berikut:

$$
\begin{gathered}
P_{i j}^{k}=\frac{\left[\tau_{i j}\right]^{\alpha}\left[\eta_{i j}\right]^{\beta}}{\sum\left[\tau_{i k^{\prime}}\right]^{\alpha}\left[\eta_{i k^{\prime}}\right]^{\beta}} \text { untuk j } \in\left\{N-t a b u_{k}\right\} \\
\mathrm{k}^{\prime} \in\left\{N-t a b u_{k}\right\}
\end{gathered}
$$

$$
\text { dan } p_{i j}^{k}-0 \text {, untuk j lainnya }
$$

dengan $\mathrm{i}$ sebagai indeks tempat asal dan $\mathrm{j}$ sebagai indeks tempat tujuan.

Langkah 4:

a. Perhitungan panjang rute setiap semut

Perhitungan panjang rute tertutup (length closed tour) atau Lk setiap semut dilakukan setelah satu siklus diselesaikan oleh semua semut. Perhitungan dilakukan berdasarkan tabuk masing-masing dengan persamaan berikut:

$\mathrm{L}_{\mathrm{k}}=d_{\text {tabu }_{k}(n), t a b u_{k}(1)}+\sum_{s=1}^{n-1} d_{\text {tabu }_{k}(s), t a b u_{k}(\mathrm{~s}+1)}$ Dengan dij adalah jarak antara tempat $\mathrm{i}$ ke tempat $\mathrm{j}$ yang dihitung berdasarkan persamaan:

$$
d_{i j}=\sqrt{\left(x_{i}-x_{j}\right)^{2}+\left(y_{i}-y_{j}\right)^{2}}
$$

b. Pencarian Jarak terpendek

Setelah Lk setiap semut dihitung, akan diperoleh harga minimal panjang rute tertutup setiap siklus atau LminNC dan harga minimal panjang jalur tertutup secara keseluruhan adalah atau Lmin.

c. Perhitungan perubahan harga intensitas jejak kaki semut antar tempat $\Delta \tau \mathrm{ij}$

Koloni semut akan meninggalkan jejak-jejak kaki pada lintasan antar tempat yang dilaluinya. Adanya penguapan dan perbedaan jumlah semut yang lewat, menyebabkan kemungkinan terjadinya perubahan harga intensitas jejak kaki semut antar tempat. Persamaan perubahannya adalah:

keterangan:

$$
\Delta \tau_{i j}=\sum_{k=1}^{m} \Delta \tau_{i j}^{k}
$$

$\mathrm{m}$ = banyak semut

$\tau i j=$ panjang jalur setiap semut 
dengan $\Delta \tau i j k$ adalah perubahan harga intensitas jejak kaki semut antar tempat setiap semut yang dihitung berdasarkan persamaan.

$$
\Delta \tau_{i j}^{k}=\frac{Q}{L_{k}}
$$

keterangan:

$\mathrm{Q}=$ tetapan siklus semut

$L k=$ length close tour (lct)

untuk (i.j) $\in$ tempat asal dan tempat tujuan dalam tabuk $\Delta \tau i j k=0$ untuk (i.j) lainnya

Langkah 5:

1. Perhitungan harga intensitas jejak kaki semut antar tempat untuk siklus selanjutnya.Harga intensitas jejak kaki semut antar tempat pada semua lintasan antar tempat ada kemungkinan berubah karena adanya penguapan dan perbedaan jumlah semut yang melewati. Untuk siklus selanjutnya, semut yang akan melewati lintasan tersebut harga intensitasnya telah berubah. Harga intensitas jejak kaki semut antar tempat untuk siklus selanjutnya dihitung dengan persamaan:

$$
\tau \mathrm{ij}=\rho . \tau \mathrm{ij}+\Delta \tau \mathrm{ij}
$$

2. Atur ulang harga perubahan intensitas jejak kaki semut antar tempat. Untuk siklus selanjutnya perubahan harga intensitas jejak semut antar tempat perlu diatur kembali agar memiliki nilai sama dengan nol

\section{Langkah 6:}

Pengosongan tabu list, dan ulangi langkah 2 jika diperlukan. Tabu list perlu dikosongkan untuk diisi lagi dengan urutan tempat yang baru pada siklus selanjutnya, jika jumlah siklus maksimum belum tercapai atau belum terjadi konvergensi. Algoritma diulang lagi dari langkah pengisian tabu list dengan harga parameter intensitas jejak kaki semut antar tempat yang sudah diperbaharui. Untuk lebih jelasnya dapat dilihat pada gambar III. 3 berikut ini:

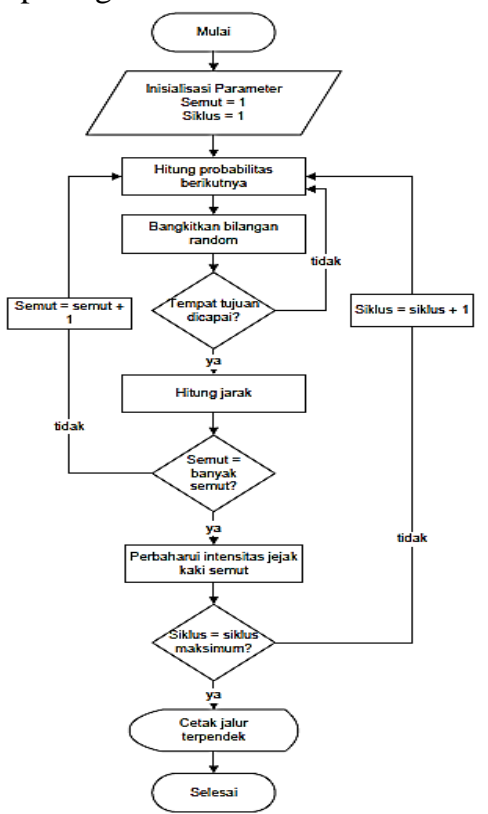

Gambar 3. Flowchart Algoritma Semut

\section{PEMBAHASAN}

Pada tahap ini merupakan kelanjutan dari hasil perhitungan algoritma yaitu penerapan perhitungan algoritma dalam menentukan jalur terpendek Tempat dikota Bandung.

Peta jalur terpendek dari Jl.permata biru - Tempat Jami Al-hidayah Jln.Manisi,Cibiru Bandung.

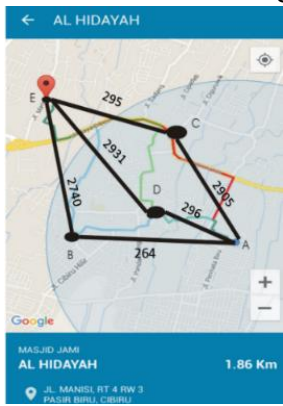

Gambar 4. Peta Jl.permata biru - Tempat Jami Alhidayah Jln.Manisi,Cibiru Bandung

Dengan jarak antar lokasi $\left(\mathrm{d}_{\mathrm{ij}}\right)$ sebagai berikut :

Tabel 1.Tabel Jarak antar lokasi

\begin{tabular}{|l|l|l|l|l|l|}
\hline & A & B & C & D & E \\
\hline A & 0 & 264 & 2905 & 296 & - \\
\hline B & 264 & 0 & - & - & 2740 \\
\hline C & 2905 & - & 0 & - & 295 \\
\hline D & 296 & - & - & 0 & 2931 \\
\hline E & - & 2740 & 295 & 2931 & 0 \\
\hline
\end{tabular}

Dari tabel diatas akan dicari rute terbaik dari titik A ke titik $\mathrm{F}$ berikut ini analisi dan langkah - langkah perhitungan rute terbaik dari titik $\mathrm{A}$ ke titik $\mathrm{E}$ menggunakan Algoritma ant colony.

Hal pertama yang harus dilakukan adalah menginisialisasi nilai parameter - parameter dari algoritma ant colony, antara lain:

1. $\mathrm{Q}=0.1$

2. $\tau i j=0.01$

3. $\alpha=0,1$

4. $\beta=1$

5. $\rho=0.5$

6. $\mathrm{m}=3$

7. $\mathrm{n}=5$

8. $\mathrm{NCmax}=1$

Menghitung visibilitas antar titik sebagai media informasi kualitas suatu edges, dengan menggunakan jarak kotak yang telah di ketahui dapat dihitung visibilitas antar kota dengan rumus $\eta i j=\left(\frac{1}{d^{i j}}\right)$

Tabel 2. Visibilitas Antar titik

\begin{tabular}{|l|l|l|l|l|l|}
\hline & A & B & C & D & E \\
\hline A & 0 & 0,003787 & 0,000344 & 0,003783 & - \\
\hline B & 0,003787 & 0 & - & - & 0,000364 \\
\hline C & 0,000344 & - & 0 & - & 0,003389 \\
\hline D & 0,003783 & - & - & 0 & 0,000341 \\
\hline E & - & 0,000364 & 0,003389 & 0,000341 & 0 \\
\hline
\end{tabular}


Tiga ekor semut mengawali perjalanan dari titik A, tiga semut mengunjungi titik sesuai jalur yang ada dengan tujuan titik E, dan tidak semua titik akan terlewati. Pada setiap langkah semut akan :

- Memilih titik yang dikunjungi secara acak

- Mencatat titik yang telah dikunjungi di dalam memori

Titik pertama yang dikunjungi semut adalah titik keberangkatan yaitu titik A. Titik pertama akan disimpan dalam memori masing - masing semut, lalu semut akan mengunjungi titik berikutnya. Proses dilakukan semut pada iterasi pertama adalah :

Visibilitas measure, $\eta(r$,$) . Dapat dihitung dengan$ persamaan :

$$
\Sigma[\tau(r, u)][\eta(r, s)] \beta=
$$

$(0,01 * 0,003787)+(0,01 * 0,000344)+(0,01 * 0,003783)$

$=0,00003787+0,00000344+0,00003783)=$ 0,00007914

a. Mengunjungi titik ke-2

Tabel 3. probabilitas kunjungan semut ke-2

\begin{tabular}{|c|c|c|c|c|c|c|c|c|}
\hline \multirow[b]{2}{*}{$\begin{array}{l}\mathrm{Se} \\
\text { mut }\end{array}$} & \multirow{2}{*}{$\begin{array}{l}\text { Titi } \\
\mathrm{k} \\
\text { Aw } \\
\text { al }\end{array}$} & \multicolumn{5}{|c|}{ Probabilitas } & \multirow[b]{2}{*}{$\mathrm{J}$} & \multirow[b]{2}{*}{$\begin{array}{l}\text { Rut } \\
\mathrm{e}\end{array}$} \\
\hline & & A & B & $\mathrm{C}$ & $\mathrm{D}$ & $\mathrm{E}$ & & \\
\hline $\mathrm{S} 1$ & A & 0 & $\begin{array}{l}0,003 \\
787 \\
\end{array}$ & $\begin{array}{l}0,000 \\
344\end{array}$ & $\begin{array}{l}0,003 \\
783\end{array}$ & 0 & B & $\begin{array}{l}{[\mathrm{A},} \\
\mathrm{B}]\end{array}$ \\
\hline $\mathrm{S} 2$ & A & 0 & $\begin{array}{l}0,003 \\
787 \\
\end{array}$ & $\begin{array}{l}0,000 \\
344 \\
\end{array}$ & $\begin{array}{l}0,003 \\
783 \\
\end{array}$ & 0 & $\mathrm{C}$ & $\begin{array}{l}{[\mathrm{A},} \\
\mathrm{C}]\end{array}$ \\
\hline $\mathrm{S} 3$ & A & 0 & $\begin{array}{l}0,003 \\
787\end{array}$ & $\begin{array}{l}0,000 \\
344\end{array}$ & $\begin{array}{l}0,003 \\
783\end{array}$ & 0 & $\mathrm{D}$ & $\begin{array}{l}{[\mathrm{A},} \\
\mathrm{D}]\end{array}$ \\
\hline
\end{tabular}

Probabilitas suatu titik bernilai nol jika titik tersebut sudah ada pada memori atau tidak ada jalur yang menghubungkan. Dari Tabel 4.3 dapat dilihat bahwa semut memilih titik dengan probabilitas terbesar, namun sebagian semut justru memilih titik dengan probabilitas kecil, hal ini menunjukan bahwa semut pada dasarnya memilih suatu titik secara acak. Isi daftar titik: $\mathrm{AB}, \mathrm{AC}$, dan $\mathrm{AD}$,

Melakukan pembaruan lokal dengan persamaan berikut

\section{$\boldsymbol{\tau}(\boldsymbol{r}, \boldsymbol{s}) \longleftarrow(\mathbf{1}-\boldsymbol{\rho}) . \tau(\boldsymbol{r}, \boldsymbol{s})+\boldsymbol{\rho} . \tau \mathbf{0}$}

Keterangan :

tetapan penguapan pheromone. Nilai ini bermanfaat agar tidak terjadi penumpukan pheromone secara tidak terbatas mengingat jumlah pheromone akan terus bertambah setiap kali iterasi.

: $(\boldsymbol{\eta} . \boldsymbol{L n n})^{-1}$ dimana $\boldsymbol{L}_{\boldsymbol{n n}}$ menyatakan jarak antara titik r ke $\mathrm{s}, \boldsymbol{\eta}$ adalah jumlah node.

$$
\begin{array}{r}
\tau(A, B)=(1-0,5) *(0,01)+(0,003787) \\
=0,008787 \\
\tau(A, C)=(1-0,5) *(0,01)+(0,000344) \\
=0,005344 \\
\tau(A, D)=(1-0,5) *(0,01)+(0,003783) \\
=0,008783
\end{array}
$$

Menghitung visibilitas meansure $\eta(r, s)$

\section{Semut 1}

$$
\Sigma[\tau(\mathrm{r}, \mathrm{u})][\eta(\mathrm{r}, \mathrm{s})] \beta=0,008787 * 0,000364
$$

$$
=0,000003198
$$

Semut 2

$$
\begin{gathered}
\begin{array}{c}
\Sigma[\tau(\mathrm{r}, \mathrm{u})][\eta(\mathrm{r}, \mathrm{s})] \beta=0,005344 * 0,003389 \\
=0,00001811 \\
\text { Semut 3 }
\end{array} \\
\begin{array}{c}
\Sigma[\tau(\mathrm{r}, \mathrm{u})][\eta(\mathrm{r}, \mathrm{s})] \beta=0,008783 * 0,000341 \\
=0,00000299
\end{array}
\end{gathered}
$$

b. Mengunjungi titik ke-3

Tabel 4. Probabilitas kunjungan titik ke-3 oleh semut

\begin{tabular}{|l|l|l|l|l|l|l|l|l|}
\hline \multirow{2}{*}{ Semut } & Titik & \multicolumn{4}{|l|}{ Probabilitas } & \multirow{2}{*}{ J } & Rute \\
\cline { 3 - 7 } & Awal & A & B & C & D & E & & \\
\hline S1 & B & $\begin{array}{l}0,003 \\
787\end{array}$ & 0 & - & - & $\begin{array}{l}0,000 \\
364\end{array}$ & E & [A,B,E] \\
\hline S2 & C & $\begin{array}{l}0,000 \\
344\end{array}$ & - & 0 & - & $\begin{array}{l}0,003 \\
389\end{array}$ & F & [A,C,E] \\
\hline S3 & D & $\begin{array}{l}0,003 \\
783\end{array}$ & - & - & 0 & $\begin{array}{l}0,000 \\
341\end{array}$ & F & [A,D,E] \\
\hline
\end{tabular}

Menghitung Pembaruan lokal

$$
\tau(B, E)=(1-0,5) *(0,01)+(0,000364)
$$

$=0,005364$

$$
\begin{gathered}
\tau(C, E)=(1-0,5) *(0,01)+(0,003389) \\
=0,008389 \\
\begin{aligned}
\tau(D, E)=(1- & 0,5) *(0,01)+(0,000341) \\
& =0,005341
\end{aligned}
\end{gathered}
$$

Menghitung visibilitas meansure $\eta(r, s)$

Semut 1

$$
\begin{gathered}
\Sigma[\tau(\mathrm{r}, \mathrm{u})][\eta(\mathrm{r}, \mathrm{s})] \beta=0,005364 * 0,000364 \\
=0,00000195 \\
\text { Semut } 2 \\
\begin{array}{c}
\Sigma[\tau(\mathrm{r}, \mathrm{u})][\eta(\mathrm{r}, \mathrm{s})] \beta=0,008389 * 0,003389 \\
=0,0000284
\end{array}
\end{gathered}
$$

\section{Semut 3}

$$
\begin{gathered}
\Sigma[\tau(\mathrm{r}, \mathrm{u})][\eta(\mathrm{r}, \mathrm{s})] \beta=0,005341 * 0,000341 \\
=0,00000182
\end{gathered}
$$

Sampai pada proses ini semut S1,S2 Dan S3 berhasil sampai ke titik tujuan yaitu titik E,tetapi semut S1 lebih cepat dikunjungi karena jarak yang di temukan semut paling dekat.

Tabel 5. Rute yang ditempuh oleh semut dari titik A ke titik E

\begin{tabular}{|l|l|l|}
\hline Semut & Rute & Jarak \\
\hline S1 & A,B,E & 3004 \\
\hline S2 & A,C,E & 3200 \\
\hline S3 & A,D,E & 3227 \\
\hline \multicolumn{2}{|l|}{ Berdasarkan Tabel 4.12 di atas dapat }
\end{tabular}

diketahui bahwa rute tebaik pada iterasii pertama adalah rute yang ditempuh oleh semut S3 dengan panjang 3004. Setelah informasi mengenai rute terbaik diperoleh, pembaruharuan pheromone global menggunakan persamaan berikut :

$$
(r, s)=(1-\alpha) \cdot \tau(r, s)+\alpha \cdot \Delta \tau(r, s)
$$

Dimana

$$
\Delta(, r, s)=\left\{\begin{array}{c}
\mathrm{Q} \\
L k
\end{array}\right.
$$


Pembaruan pheromone global untuk rute tebaik pada iterasi pertama. Rute terbaik adalah [A,B,E] dengan panjang 3004, maka:

$$
\begin{gathered}
\Delta \tau(r, s)=\frac{0,1}{3004}=0,0000332 \\
\text { Maka, } \\
(r, s)=(1-\alpha) \cdot \tau(r, s)+\alpha . \Delta \tau(r, s) \\
\tau(A, B)=(1-0,1) * 0,005344+0,1 * 0,0000332 \\
=0,000003336 \\
\tau(C, E)=(1-0,1) * 0,008389+0,1 * 0,0000332 \\
=0,00075833
\end{gathered}
$$

Pembaharuan pheromone global untuk rute yang lain.

$$
\Delta(r, s)=0 \text {, makanilai } . \Delta \tau(r, s)=1 * 0=0
$$

$$
(r, s)=(1-\alpha) \cdot \tau(r, s)+0
$$

$\tau(A, D)=(1-0,1) * 0,008783=0,0079047$

$\tau(A, B)=(1-0,1) * 0,008787=0,0079083$

$\tau(D, E)=(1-0,1) * 0,005341=0,0048069$

$\tau(B, E)=(1-0,1) * 0,005364=0,0048278$

Tabel 6. Nilai pheromon antar titik

\begin{tabular}{|l|l|l|l|l|l|}
\hline F & A & B & C & D & E \\
\hline A & 0 & 0,0079083 & 0,00003336 & 0,0079047 & \\
\hline B & 0,0079083 & 0 & & & 0,0048278 \\
\hline C & 0,00003336 & & 0 & & 0,0075833 \\
\hline D & 0,0079047 & & & 0 & 0,0048069 \\
\hline E & & 0,0048278 & 0,0075833 & 0,0048069 & 0 \\
\hline
\end{tabular}

perubahan nilai pheromone. Jalan yang sering dikunjungi semut akan terjadi peningkatan nilai pheromone, sedangkan pada jalan yang jarang dikunjungi semut terjadi pengurangan nilai pheromone. Nilai pheromone yang baru inilah yang akan digunkan pada perhitungan iterasi berikutnya.

\section{V.Kesimpulan}

Berdasarkan pembahasan penelitian yang sudah penulis buat, maka dapat diambil kesimpulan sebagai berikut :

1. Telah berhasil membuat aplikasi SIG pencarian Tempat Ibadah terdekat kota Bandung berbasis Android.

2. Telah berhasil menerapkan algoritma Ant Colony Optimization pada aplikasi.Pencarian Tempat Ibadah terdekat di Kota Bandung.

3. Aplikasi ini dapat menampilkan info lokasi Tempat Ibadah beserta rute terpendek pada peta.

4. Aplikasi ini dapat membantu para wisatawan dalam mencari Tempat Ibadah terdekat tanpa bertanya-tanya pada masyarakat sekitar.

5. Aplikasi ini mejadikan Google Map API sebagai pemetaannya.

6. Aplikasi ini mengefesienkan waktu user dalam mencari Tempat Ibadah terdekat.

\section{REFERENSI}

[1] Linden (1987). Quantum GIS halaman 1-20.

[2] Pressman, Roger S. 2002. Rekayasa Perangkat Lunak : Pendekatan Praktisi (Buku Satu). Yogyakarta : Andi Offset.

[3] E. Ayub ,Mohammad. 1996. Manajemen Masjid, Jakarta: Gema Insani Press.

[4] Sudharta, Tjok. Rai (2006) Beda Sadkahyangan dengan Sadwinayaka, Kolom Tatwa. Majalah Sarad Bali, Ed. No. 69/Tahun VII.

[5] Dorigo,M dan Gambardella,L.M., Ant Colony System:A Cooperative Learning Approach to theTraveling Salesman Problem, UniversitéLibre de Bruxelles Belgium,1996. 